\title{
Selected English-Language Bibliography of Interest for Hungarian Cultural Studies: 2017-2018
}

\section{Zsuzsanna Varga}

\begin{abstract}
As the above title indicates, because of the publication schedule of Hungarian Cultural Studies this bibliography straddles 2017-2018, covering the period since the publication in Fall of 2017 of last year's bibliography in this journal. Each year's bibliography may also be supplemented by earlier items, which were retrieved only recently. Although this bibliography series can only concentrate on English-language items, occasional items of particular interest in other languages may be included. For a more extensive bibliography of Hungarian Studies from about 2000 to 2010, for which this is a continuing update, see Louise O. Vasvári, Steven Tötösy de Zepetnek, and Carlo Salzani. "Bibliography for Work in Hungarian Studies as Comparative Central European Studies." CLCWeb: Comparative Literature and Culture (Library) (2011): http://docs.lib.purdue.edu/clcweblibrary/hungarianstudiesbibliography.
\end{abstract}

Keywords: In nec, urna turpis, varius tempor, sed et est

Biography: Zsuzsanna Varga studied English, Hungarian and Portuguese language and literature at Eötvös Loránd University, Budapest. She received her PhD in nineteenth-century English literature at Edinburgh University. She has taught and researched at different British universities, including the University of Essex, UCL and De Montfort University. She has taught Hungarian Studies at Glasgow University since 2008, and she is also in charge of the Hungarian library collection at the University of Oxford. Her research interests include nineteenth-century women's writing, travel writing and translation history.zsuzsanna.varga@glasgow.ac.uk

Apor, Balázs. 2018. The Invisible Shining: The Cult of Mátyás Rákosi in Stalinist Hungary, 1945-1956. Budapest: CEU P.

Bak, János M., Patrick J. Geary, and Gábor Klaniczay, eds. 2015. Manufacturing a Past for the Present: Forgery and Authenticity in Medievalist Texts and Objects in Nineteenth-Century Europe. Leiden: Brill.

Balázs, Imre József. 2018. “Trees, Waves, Whirlpools: Nation, Region, and the Reterritorialization of Romania's Hungarian Literature.” Romanian Literature as World Literature. Eds. Mircea Martin, Christian Moraru, and Andrei Terian. New York, NY: Bloomsbury Academic: 157-173.

Barát, Erzsébet. 2017. "Populist Discourses in the Hungarian Public Sphere: From Right to Left (and Beyond)." Journal of Language and Polity 16.4: 535-550. 
Varga, Zsuzsanna. "Selected English-Language Bibliography of Interest for Hungarian Cultural Studies: 2017-

2018." Hungarian Cultural Studies. e-Journal of the American Hungarian Educators Association, Volume 11 (2018) DOI: $10.5195 /$ ahea.2018.328

Becker, András. 2017. "British Strategy in Hungary in 1944 and the Hungarian Jewish Commandos of the Special Operations Executive." Hungarian Studies Review 44.1-2: 81104.

Berger, Stefan and Alexei Miller, eds. 2015. Nationalising Empires. Budapest: CEU P. Berlász, Melinda. 2018. 'Zoltán Kodály’s 'Journey of Triumph' in Santa Barbara, California." Hungarian Review 9.2: 89-102.

Bertha, Csilla. 2017. "The Happening of Truth-Editing an Anthology on the 1956 Hungarian Revolution." Hungarian Review 8.5: 45-54.

Bezsenyi Tamás and András Lénárt. 2017. "The Legacy of World War II and Belated Justice in the Hungarian Films of the Early Kádár Era." Hungarian Historical Review 6.2: 300-327.

Bódi, Lóránt. 2017. “The Documents of a Fresh Start in Life: Marriage Advertisements Published in the Israelite Newspaper Új Élet (New Life) Between 19451952." Hungarian Historical Review 6.2: 404-426.

Bodó, Béla. 2017. "Memory Practices: The Red and White Terrors in Hungary as Remembered after 1990." East Central Europe 44.2-3:186-215.

Brodbeck, David. 2017. "'Heimat' is Where the Heart is; or, What Kind of Hungarian was Goldmark?” Austrian History Yearbook 48: 235 -254.

Brunnbauer, Ulf. 2017. "Introduction to the Special Issue: Migration and East Central Europe - a Perennial but Unhappy Relationship." Hungarian Historical Review 6.3: 497-501.

Chan, Roy Bing. 2017."Homelessness in the World: War, Narrative and Historical Consciousness in Eileen Chang, György Lukács, and Lev Tolstoy.” Journal of Modern Literature in Chinese 14.1:1-29.

Codău, Annamária. 2017. "The Acta Comparationis Litterarum Universarum (1877-1888) from the Perspective of its British Collaborators." Hungarian Cultural Studies 10: 106-119. https://ahea.pitt.edu/ojs/index.php/ahea/article/view/299

Cooper, David. 2018. Béla Bartók: The Definitive Account of the Life and Music of Hungary's Greatest Twentieth-Century Composer. New Haven: Yale UP.

Cooper, Thomas. 2017. "Hungarian Voices on the 1956 Revolution: Down Fell the Statue of Goliath.” Hungarian Review 8.5: 38-44.

Courtman, Nicholas. 2018. "Seeing the Human in the (Queer) Migrant in Jenny Erpenbeck's Gehen, Ging, Gegangen and Terézia Mora's Alle Tage.” Edinburgh German Yearbook. Ed. Leanne Dawson. 10: 153-176.

Davis, Chris R. 2018. Hungarian Religion, Romanian Blood: A Minority's Struggle for National Belonging, 1920-1945. Madison, WI: University of Wisconsin UP.

Davis, Sacha E. 2017. "Competitive Civilizing Missions: Hungarian Germans, Modernization, and Ethnographic Descriptions of the 'Zigeuner' before World War I." Central European History 50.1: 6-33.

Deák, Anita. 2017. "Irony and Intertextuality in Cat City." Hungarian Studies 31.1: 61-69.

Dobrenko, Evgeny and Natalia Jonsson-Skradol, eds. 2018. Socialist Realism in Central and Eastern European Literatures under Stalin. London: Anthem P.

Dresziger, Nándor. 2016. Church and Society in Hungary and in the Hungarian Diaspora. Toronto: Toronto UP.

Dresziger, Nándor. 2016. Footprints: The Hungarian Legacy in Canada. Kingston, ON: The Hungarian Studies Review. 
Varga, Zsuzsanna. "Selected English-Language Bibliography of Interest for Hungarian Cultural Studies: 2017-

2018." Hungarian Cultural Studies. e-Journal of the American Hungarian Educators Association, Volume 11 (2018) DOI: $10.5195 /$ ahea.2018.328

Dukkon, Ágnes. 2017. "Sign - Symbol - Decoration: The Relationship of Image and Text in $16^{\text {th }}$ $-17^{\text {th }}$ Century Hungarian Calendars." Hungarian Studies 31.1: 95-112.

Egry, Gábor. 2017. "Unholy Alliances? Language Exams, Loyalty, and Identification in Interwar Romania." Slavic Review 76.4: 959-982.

Erös, Vilmos. 2017. "Ethnohistory in Hungary between the Two World Wars: Elemér Mályusz and István Szabó." Hungarian Studies Review 44.1-2: 53-80.

Farkas, Ákos. 2017. "Gendered Peace: Four Hungarian Women Writers Against the Two World Wars.” Slavonica 22.1-2: 39-53.

Farkas, Judit. 2017. "'There Are No Recipes.' An Anthropological Assessment of Nutrition in Hungarian Ecovillages.” Acta Ethnographica Hungarica 62.2: 319-338.

Feigelson, Kristian and Catherine Portuges. 2017. "Screen Memory: The Jewish Question." Hungarian Studies 31.1: 19-38.

Fejös, Zoltán. 2017. "Hungarian Folk Art Exhibitions in the USA in 1914." Hungarian Studies Review 44.1-2: 5-35.

Ferdinand, Siarl and Flóra Komlósi. 2017. "The Use of Hungarian and Serbian in the City of Szabadka/Subotica: An Empirical Study.” Hungarian Cultural Studies 10: 1-13. https://ahea.pitt.edu/ojs/index.php/ahea/article/view/278

Fichtner, Paula Sutter. 2017. "Sibling Bonding and Dynastic Might: Three Sixteenth-Century Habsburgs Manage Themselves and an Empire.” Austrian History Yearbook 48: 193211.

Fodor, Péter. 2017. "Erasing, Rewriting, and Propaganda in the Hungarian Sports Films of the 1950s." Hungarian Historical Review 6.2: 328-354.

Frey, David. 2018. Jews, Nazis and the Cinema of Hungary: The Tragedy of Success, 1929-44. London: IB Tauris.

Gecser, Ottó. 2017. "St Sebastian and St Roche as Plague Saints and Their Cult in Medieval Hungary." Les saints et leur culte en Europe centrale au Moyen Âge. Eds. MarieMadelaine de Cevins and Olivier Marin. Turnhout: Brepols: 77-108.

Gergely, Gábor. 2017. Hungarian Film 1929-1947: National Identity, Anti-Semitism and Popular Cinema. Amsterdam: Amsterdam UP.

Gioielli, Emily R. 2017. "Home Is Home No Longer" Political Struggle in the Domestic Sphere in Post-Armistice Hungary, 1919-1922." Aspasia 11.1: 54-70.

Godsey, William D. 2015. Forging a Multinational State: State Making in Imperial Austria from the Enlightenment to the First World War. Standford: Stanford UP.

Grzebalska, Weronika and Andrea Petö. 2018. "The Gendered Modus Operandi of the Illiberal Transformation in Hungary and Poland." Women's Studies International Forum 68.3: 164-172.

Györi, Zsolt. 2017. "Discursive (De)Constructions of the Depoliticized Private Sphere in The Resolution and Balaton Retro." Hungarian Historical Review 6.2: 271-299.

Györke, Ágnes. 2005. "Nation and Gender in The Eclipse of the Crescent Moon." Neohelicon 32.1: 129-136.

Hajdu, Péter. 2017. "The Case of Mór Jókai and the Detective Story." Hungarian Cultural Studies 10: 133-144. https://ahea.pitt.edu/ojs/index.php/ahea/article/view/300

Hajdu, Péter. 2017. "The Rights of Trees: On a Hungarian Short Story from 1900.” Neohelicon 44.2: 389-401. 
Varga, Zsuzsanna. "Selected English-Language Bibliography of Interest for Hungarian Cultural Studies: 2017-

2018." Hungarian Cultural Studies. e-Journal of the American Hungarian Educators Association, Volume 11 (2018) DOI: $10.5195 /$ ahea.2018.328

Hajnáczky Tamás. 2017. "The Elimination of the Tibolddaróc Cave Dwellings: Non-Gypsies in the CS Housing Program.” Acta Ethnographica Hungarica 62.2: 407-440.

Hamerli, Petra. 2017. "Croatian Political Refugees Living in Emigration in the Interwar Period: The Case of the Croatian Political Refugees in Hungary." Hungarian Historical Review 6.3: 624-646.

Heltai, Gyöngyi. 2016. "Star Prima Donnas as Lieux de Mémoire at Home and Abroad." World Literature Studies 8.4: 64-76.

Hites, Sándor. 2018. "How to Begin and How to End National Narratives: Histories of Literature and Economic Thought in $19^{\text {th }}$ Century Hungary." Festschrift for Péter Dávidházi. Eds. Dániel Panka, Natália Pikli and Veronika Ruttkay. Budapest: ELTE BTK: 163-170.

Indelicato, Alberto. 2017. “Two Italians against Béla Kun.” Hungarian Review 8.5: 86-95.

Iveljic, Iskra, ed. 2015. The Entangled Histories of Vienna, Zagreb and Budapest (18th-20th Century) = Verflechtungsgeschichte: Wien, Zagreb und Budapest (18.-20. Jahrhundert). Zagreb: Faculty of Humanities and Social Sciences, University in Zagreb.

Jankó, Ferenc and Steven Jobbit. 2017. "Making Burgenland from Western Hungary: Geography and the Politics of Identity in Interwar Austria." Hungarian Cultural Studies 10: 14-40. https://ahea.pitt.edu/ojs/index.php/ahea/article/view/313

Kádár, Judit. 2017. "Republishing Pre-World War II Hungarian Women Writers After the Fall of Socialism." Hungarian Cultural Studies 10: 41-53. https://ahea.pitt.edu/ojs/index.php/ahea/article/view/276

Kalavszky, Zsófia. 2017. "The Pushkin Myth and Cult in Central European Literature: Gyula Krúdy's A vörös postakocsi ['The Crimson Coach'] (1913).” Hungarian Cultural Studies 10: 120-132. https://ahea.pitt.edu/ojs/index.php/ahea/article/view/295

Kálmán, György C. and Zoltán Z. Varga. 2017. "Introduction to Comparative Studies in the Central European Context." Hungarian Cultural Studies 10: 96-105. https://ahea.pitt.edu/ojs/index.php/ahea/article/view/306

Kálmán, György C. 2017. "Avant-Garde Studies in the Institute for Literary Studies of the Hungarian Academy of Sciences." Local Contexts / International Networks. The AvantGarde and its Journals, 2. Budapest: Petőfi Literary Museum; Kassák Museum; Kassák Foundation: 183-187.

Keszeg Anna. 2017. "Media Nostalgia in Contemporary Hungarian Pop Music." Hungarian Studies 31.2: 223-234.

Kiss, Csilla. 2015. "Divided Memory in Hungary: The House of Terror and the Lack of a LeftWing Narrative." Life Writing and Politics of Memory in Eastern Europe. Ed. Simona Mitroiu. London: Palgrave Macmillan: 242-259.

Klein, Rudolf. 2017. Synagogues in Hungary: 1782-1918. Budapest: Terc.

Klein-Pejšová, Rebekah. 2017. "The Budapest Jewish Community's Galician October.” World War I and the Jews: Conflict and Transformation in Europe, the Middle East and America. Eds. Marsha L. Rozenblit and Jonathan Karp. Oxford: Berghahn.

Kókai, Károly. 2017. "The Evidence of the Avant-Garde film." Hungarian Studies 31.1: 39-46. Konrád, Miklós. 2018. "Narrating the Hungarian-Jewish National Past: The "Khazar Theory" and the Integrationist Jewish Scientific Discourse." Cultural Nationalism in a FinnishHungarian Historical Context. Eds. Gábor Gyáni and Anssi Halmesvirta. Budapest: MTA: 49-61. 
Varga, Zsuzsanna. "Selected English-Language Bibliography of Interest for Hungarian Cultural Studies: 2017-

2018." Hungarian Cultural Studies. e-Journal of the American Hungarian Educators Association, Volume 11 (2018) DOI: $10.5195 /$ ahea.2018.328

Köttig, Michaela, Renate Bitzan, and Andrea Petö, eds. 2016. Gender and Far Right Politics in Europe. Cham, Switzerland: Palgrave Macmillan.

Kovács, Dániel. 2017. "World Language with an Accent- Art Deco in Central Europe." Hungarian Review 8.6: 114-122.

Kuligowski, Waldemar. 2017. "Collective Vertigo: Roger Caillois 'théorie de la fête' Toward Contemporary Music Festivals in Poland and Hungary." Acta Ethnographica Hungarica 62.2: 389-406.

Kunt, Gergely. 2017. "Republishing Pre-World War II Hungarian Women Writers After the Fall of Socialism." Hungarian Cultural Studies 10: 54-67.

https://ahea.pitt.edu/ojs/index.php/ahea/article/view/279

Kürti, László. 2017. "The Plow and the Stallion: Political Turmoil in a Working-Class District of Budapest." The Palgrave Handbook of Urban Ethnography: 221-240.

Kürti, László. 2016. "Nomadism and Nostalgia in Hungary." Memories on the Move: Experiencing Mobility, Rethinking the Past. London: Palgrave Macmillan: 217-246.

Laczó, Ferenc. 2015. "Caught Between Historical Responsibility and the New Politics of History: On Patterns of Hungarian Holocaust Remembrance." Life Writing and Politics of Memory in Eastern Europe. Ed. Simona Mitroiu. London: Palgrave Macmillan:185-201.

Laczó, Ferenc. 2018. "New Sensibilities, New Volatilities. Antisemitism in Contemporary Hungary." Antisemitism Studies 2.1: 75-108.

Laczó, Ferenc. 2018. "Beyond Helpless Victims and Survivor Trauma: New Historiography on Jews in the Age of the Holocaust." Contemporary European History 1-15.

Lakatos, Artur. 2016. "The treatment of the Jewish issue in the Roman Catholic, Calvin Protestant and Unitarian Printed Media, Transylvania 1920-1944." Churches-Holocaust: Christian Churches in Three Countries of Central and Eastern Europe and the Holocaust. Eds. Erika Törzsök and Attila Jakab. Budapest: Civitas Europa Centralis: 178-220.

Lakatos, Artur. 2013. "Current Situation in Ecclesiastic Archives in Transylvania, Romania." Archives for Maintaining Community and Society in the Digital Age. Ed. Keiji Fuyijoshi. Koyosan University: Wakayama: 85-92.

Lampland, Marta and Maya Nadkarni. 2016. "Whatever Happened to Jokes? The Shifting Landscape of Humor in Hungary." East European Politics and Societies 30.2: 449-471.

Laszlovszky, József, Balázs Nagy, Péter Szabó and András Vadas, eds. 2018. The Economy of Medieval Hungary. Leiden: Brill.

Lénárt, István. 2017. "Association and Verbal Consciousness: An Analysis Based on Four English and One Hungarian Translation of Bulgakov's Novel The Master and Margarita." Neohelicon 44.2: 487-504.

Litkei, József. 2017. "The Molnár Debate of 1950: Hungarian Communist Historical Politics and the Problem of the Soviet Model." East Central Europe 44.2-3: 249-283.

Mark, James. 2017. "'The Spanish Analogy': Imagining the Future in State Socialist Hungary, 1948-1989." Contemporary European History 26.4: 600-620.

Menyhért, Anna. 2017. "Digital Trauma Processing in Social Media Groups: Transgenerational Holocaust Trauma on Facebook." Hungarian Historical Review 6.2: 355-376.

Mervay, Mátyás. 2018. "Austro-Hungarian Refugee Soldiers in China.” Journal of Modern Chinese History 12.1. 
Varga, Zsuzsanna. "Selected English-Language Bibliography of Interest for Hungarian Cultural Studies: 2017-

2018." Hungarian Cultural Studies. e-Journal of the American Hungarian Educators Association, Volume 11 (2018) DOI: $10.5195 /$ ahea.2018.328

Mészáros Csaba et al. 2017. "Ethnographic Accounts of Visitors from the Austro-Hungarian Monarchy to the Asian Peripheries of Russia and their Contribution to the Development of Systematic Ethnological Studies in the Monarchy: Preliminary Results and Research Perspective." Acta Ethnographica Hungarica 62.2: 465-498.

Metro-Roland, Michelle Marie. 2013. "Goulash Nationalism: The Culinary Identity of a Nation." Journal of Heritage Tourism 8.2-3: 172-181.

Monok István. 2017. "Cultural Ideals: Changes in Patterns of Knowledge (from the Point of View of Reading History)." Hungarian Studies 31.2: 251-270.

Nemes, Robert. 2016. Another Hungary: The Nineteenth-Century Provinces in Eight Lives. Stanford: Stanford UP.

Niessen, James P. 2017. "God Brought the Hungarians: Emigration and Refugee Relief in the Light of Cold War Religion." Hungarian Historical Review 6.3: 566-596.

Oancea, Sever Cristian. 2017. "Integration Through Confession? Lutheran Migration from Upper Hungary to Sibiu After 1671 - Isaak Zabanius.” Hungarian Historical Review 6.3: 502519.

Olin, Timothy. 2017. "Cultivating an Orderly Society: Physical and Mental Landscapes on the Habsburg's Southern Frontiers." Austrian History Yearbook 48: 159-172.

Oltay, Edith. 2017. "Concepts of Citizenship in Eastern and Western Europe." Acta Universitatis Sapientiae, European and Regional Studies 11.1: 43-62.

Palazzetti, Nicolò. 2016." "The Bartók Myth. Fascism, Modernism and Resistance in Italian Musical Culture." International Review of the Aesthetics and Sociology of Music 47.2: 289-314.

Parsons, Nicholas T. 2017. "Motherland and Progress: Hungarian Architecture and Design 18001900. Hungarian Review 8.5: 109-123.

Peterecz Zoltán. 2017. "Reflection of and about Hungary in the English-Speaking World in the Interwar Years." Hungarian Studies 31.2: 237-250.

Péteri, György. 2017. "External Politics--Internal Rivalries Social Science Scholarship and Political Change in Communist Hungary." East Central Europe 44.2-3: 309-339.

Petö, Andrea. 2017. "Roots of Illiberal Memory Politics: Remembering Women in the 1956 Revolution." Baltic Worlds 10.4: 42-58.

Plainer, Zsuzsa. 2018. "'Everybody Loved Each Other There': Roma Memories of the One-Time Cinka Panna Colony in Oradea and Its Liquidation during the Communist Times." East European Politics and Societies 32.2:1-24.

Pogonyi, Szabolcs. 2017. "Europeanization of Kin-Citizenship and the Dynamics of KinMinority Claim-Making: The Case of Hungary." Problems of Post-Communism 64.5: 242-256.

Poznan, Kristina E. 2017. "Return Migration to Austria-Hungary from the United States in Homeland Economic and Ethnic Politics and International Diplomacy." Hungarian Historical Review 6.3: 647-667.

Quigley, Colin. 2014. "The Hungarian Dance House Movement and Revival of Transylvanian String Band Music." The Oxford Handbook of Music Revival. Eds. Caroline Bithell and Juniper Hill. Oxford: Oxford UP.

Rainer, János. 2017. "Discourses of Contemporary History in Hungary after 1989: A Fragmented Report." East Central Europe 44.2-3: 216-248. 
Varga, Zsuzsanna. "Selected English-Language Bibliography of Interest for Hungarian Cultural Studies: 2017-

2018." Hungarian Cultural Studies. e-Journal of the American Hungarian Educators Association, Volume 11 (2018) DOI: $10.5195 /$ ahea.2018.328

Rákai Zsuzsa. 2017. “'New Classicism' and the Music of 'New Humanity' - Hungarian Music Historiography and Bence Szabolcsi." Hungarian Studies 31.2: 191-198.

Renner, Steven. 2016. Broken Wings. The Hungarian Air Force, 1918-45. Bloomington, IN: Indiana University Press.

Réti, Zsófia. 2017. "Past Traumas and Future Generations: Cultural Memory Transmission in Hungarian Sites of Memory." Hungarian Historical Review 6.2: 377-403.

Roguska, Magdalena. 2017. "The Hungarian-French Language Shift in Agota Kristof's The Illiterate." Moving Texts, Migrating People and Minority Languages. Heidelberg: Springer: 69-78.

Rosen, Ilana. 2017. "The Representation of Jews in Nineteenth- and Twentieth-Century Hungarian Proverb Collections." Hungarian Cultural Studies 10: 68-80. https://ahea.pitt.edu/ojs/index.php/ahea/article/view/280

Salagean, Tudor. 2016. Transylvania in the Second Half of the Thirteenth Century. The Rise of the Congregational System. Leiden: Brill.

Saral, Emre. 2017. "A Foreign Labor Force in Early Republican Turkey: The Case of Hungarian Migrant Workers." Hungarian Historical Review 6.3: 597-623.

Sárközi, Mátyás. 2017. "Extra Hungariam - on the Intellectual Life of the Hungarian Exiles after 1956." Hungarian Review 8.5: 59-65.

Scheibner, Tamás. 2018. "Introducing Socialist Realism in Hungary, 1945- 51: How Politics Made Aesthetics." Socialist Realism in Central and Eastern European Literatures under Stalin: Institutions, Dynamics, Discourses. Eds. Evgeny Dobrenko and Natalia JonssonSkradol. London: Anthem: 237-259.

Schwartz, Agatha and Helga Thorson, eds. 2014. Shaking the Empire, Shaking Patriarchy: The Growth of a Feminist Consciousness across the Austro-Hungarian Monarchy. Riverside, CA: Ariadne Press.

Schwartz, Agatha. 2017. "Creating a 'Vocabulary of Rupture' Following WWII Sexual Violence in Hungarian Women Writers' Narratives." Hungarian Cultural Studies 10: 81-95. https://ahea.pitt.edu/ojs/index.php/ahea/article/view/281

Seegel, Steven. 2018. Map Men: Transnational Lives and Deaths of Geographers in the Making of East Central Europe. Chicago: Chicago UP.

Sherwood, Peter. 2018. "Kossuth and Solidarity." SSEIR 96.2: 313-328.

Shneer, David. 2017. "The Elusive Search for Evidence: Evgenii Khaldei's Budapest Ghetto, Images of Rape, and Soviet Holocaust Photography." Slavic Review 76.1: 80-89.

Snopek, Jerzy. 2018. "A Friend of Czesław Miłosz and Zbigniew Herbert—George Gömöri under Polish Eyes." Hungarian Review 9.1.

Snopek, Jerzy. 2017. "Two Great Reformers: Andrzei Zamoyski and István Széchenyi." Hungarian Review 8.5: 77-85.

Stewart. Fiona. 2014. '’The Parting of Ways:' The Shifting Relationship between Anna Lesznai and Emma Ritoók, and the Restructuring of Hungarian Cultural and Political Life in the Early 1920s." Hungarian Studies Review 41.1-2: 35-60. http://epa.oszk.hu/00000/00010/00049/pdf/EPA00010_hsr_2014_035-060.pdf

Swanson, John C., ed. 2016. Tangible Belonging: Negotiating Germanness in TwentiethCentury Hungary. Pittsburgh, PA: Pittsburgh UP.

Szapor, Judit. 2017. Hungarian Women's Activism in the Wake of the First World War: From Rights to Revanche. London: Bloomsbury. 
Varga, Zsuzsanna. "Selected English-Language Bibliography of Interest for Hungarian Cultural Studies: 2017-

2018." Hungarian Cultural Studies. e-Journal of the American Hungarian Educators Association, Volume 11 (2018) DOI: $10.5195 /$ ahea.2018.328

Széchenyi, Ágnes. 2017. “A Hungarian Author in the World of Cinema: Lajos (Ludwig) Bíró (1890-1948)." Hungarian Studies Review 44.1-2: 37-52.

Szolláth, Dávid. 2017. "Literary Modernism, Anti-Semitism, Jewishness and the Anxiety of Assimilation in Interwar Hungary." Hungarian Cultural Studies 10: 145-157. https://ahea.pitt.edu/ojs/index.php/ahea/article/view/296

Szombati, Kristóf. 2018. The Revolt of the Provinces: Anti-Gypsyism and the Right-Wing Politics in Hungary. Oxford: Berghahn.

Takács, Ádám. 2017. “The Heads and the Walls. From Professional Commitment to Oppositional Attitude in Hungarian Sociology in the 1960-1970s: The Cases of András Hegedüs, István Kemény, and Iván Szelényi.” Hungarian Historical Review 6.4: 856882.

Tófalvi, Zoltán. 2017. "Death March Redux: The '56 Revolutionaries of Transylvania." Hungarian Review 8.5: 66-76.

Vaderna, Gábor, 2017. "Censorship and the Faces of Hungarian Conservatism in the First Decades of the Nineteenth Century." Austrian History Yearbook 48: 91-105.

Valkola, Jarmo. 2017. "Metaphysical Essentialism - the Pictorial Harmony of Béla Tarr's Films." Hungarian Studies 31.1: 3-18.

Varga, Sándor. 2016. "The Influence of Dance-House Tourism on the Social Relationships and Traditions of a Village in Transylvania.” Tr. Valér Bedő (with Colin Quigley). Ethnomusicology Translations 4: 1-17.

Varsa, Eszter. 2017. “The (Final) Solution of the 'Gypsy-Question:' Continuities in Discourses about Roma in Hungary, 1940s-1950s." Nationalities Papers 45.1: 114-130.

Waterbury, Myra A. 2017. "National Minorities in an Era of Externalization: Kin-State Citizenship, European Integration, and Ethnic Hungarian Minority Politics.” Problems of Post-Communism 64.5: 228-241.

Zelenková, Anna and Ján Gbúr. 2017. "Unknown Hungarian First Fruits of the Slovak Poet Pavol Országh Hviezdoslav.” Neohelicon 44.2: 469-485.

Zimmermann, Susan and Piroska Nagy. 2018. "Female Agrarian Workers in Early TwentiethCentury Hungary: The Making of Class- and Gender-Based Solidarities." Aspasia 12.1: 121-133.

Zvara, Edina. 2017. "Scholarly Translators and Committed Disputants: The First Century of the Hungarian Bible." Hungarian Studies 31.2: 271-282. 